\title{
Lähiruoasta lisäarvoa paikallisille elintarvikeketjuille?
}

\author{
Jaana Paananen ${ }^{1)}$, Sari Forsman ${ }^{2)}$ \\ ${ }^{1)}$ MTT Taloustutkimus, PL 3, 00411 Helsinki, jaana.paananen@mtt.fi \\ ${ }^{2)}$ MTT Taloustutkimus, PL 3, 00411 Helsinki,sari.forsman@mtt.fi
}

\section{Johdanto}

Kiinnostus lähiruokatoimintaan sekä taloudellisesti, sosiaalisesti ja ekologisesti kestäviin ruokaketjuihin on kasvanut Suomessa erityisesti viime vuosina. Vaihtoehtoisten elintarvikkeiden tarjontaketjujen kehittäminen on yksi tapa edistää maaseudun elinvoimaisuutta ja tukea kansallista elintarvikestrategiaamme. Maaseutupolitiikan näkökulmasta lähiruokatoiminta ja muut perinteisiä tarjontaketjuja lyhyemmät vaihtoehtoiset ruokaketjut edustavat uusia toimintamalleja maaseudun kehittämisessä (La Trobe ja Abott 2000, Marsden ja Arce 1995, Marsden 2000, Marsden ym. 2000).

Tietoinen panostaminen lähiruokatuotannon kehittämiseen ja hyödyntämiseen tarjoaa uuden näkökulman maaseudun pienyritysten tuotteiden ja palvelujen markkinointiin. Lähiruokatoiminnalla tarkoitetaan vaihtoehtoista elintarvikkeiden tarjontaketjua, joka perustuu alueellisten tai paikallisten markkinoiden hyödyntämiseen ja jossa myyjän ja ostajan välinen vuorovaikutus on aktiivista. Lähiruokatoiminnassa tuottajan ja asiakkaan välinen fyysinen ja toimitusajallinen yhteys on mahdollisimman lyhyt, ja elintarvikkeiden välivarastointia ja jakeluportaiden määrää pyritään minimoimaan.

Tutkimuksessa lähiruokaa tarkastellaan tuotteistamis- ja markkinointimahdollisuutena maaseudun pienten elintarvikeyritysten näkökulmasta. Tavoitteena oli tarkastella lähiruokatuotantoa ja -toimintaa osana elintarvikeketjun asiakaslähtöistä lisäarvon muodostamista. Lähtökohtana oli oletus, että lähiruokatoimintamalli muodostaa ketjun eri toimijoiden näkökulmasta hyötyjä, jotka luovat lisäarvoa pienyrityksen ja asiakkaan välisessä kaupallisessa suhteessa. Olettamus perustuu siihen, että elintarvikkeiden suoralla tarjontaketjulla on myönteinen vaikutus sekä tuotteiden ominaisuuksiin että myyjä-ostajasuhteeseen. Tuotteen tuoreuden oletetaan olevan parempi suorassa toimituksessa tuottajalta asiakkaalle kuin epäsuorassa, usean välivarastoinnin kautta kulkevassa toimituksessa (Markula 1999, s. 14). Lisäksi suora tarjontaketju mahdollistaa aukottoman tiedonvaihdon myyjä-ostajasuhteen eri vaiheissa (Aro 1998, s. 30). Suoran tarjontaketjun myönteisten vaikutuksien kautta sen oletetaan lisäävän eri toimijoiden menestymistä elintarvikeketjussa. Tutkimuksen pääongelma oli, miten lähiruokatoimintamallia on elintarvikeketjun eri toimijoille syntyvän lisäarvon näkökulmasta mahdollisuus hyödyntää maaseutuyrityksen kilpailutekijänä.

Tutkimus asemoituu teoreettisesti arvopohjaisten teorioiden ja mallien tarkasteluun sekä tarjontaketjujen strategiseen johtamiseen. Lähiruokaa ja suoraa tarjontaketjua tarkastellaan tutkimuksessa potentiaalisena lisäarvon lähteenä ja siten kilpailutekijänä pienyrityksissä. Asiakaslähtöinen lisäarvon muodostaminen perustuu asiakkaiden odotusten (tarpeiden), toimintatapojen ja kokemusten (hyödyt, uhraukset ja riskit) tunnistamiseen (Kemperman ja van Engelen 1999, Ravald ja Grönroos 1996, Ravald 2001, Woodruff 1997). Näiden asiakasarvon eri komponenttien tunnistamiselle ja määrittämiselle voidaan olettaa olevan hyvät lähtökohdat toimijoiden keskinäiseen läheisyyteen ja tiiviiseen vuorovaikutukseen perustuvassa lähiruokatoiminnassa. Toimijoiden välinen vastavuoroinen riippuvuus tiedosta ja sen vaihdosta on hyvä perusta koko elintarvikeketjun arvon muodostukselle ja pienten yritysten menestymismahdollisuudelle markkinoilla. Yrityksissä lisäarvoa luovia tekijöitä voi muodostua fyysisistä tuoteominaisuuksista, palvelu- tai mielikuvatekijöistä sekä yrityksen tuotanto- ja toimintatapaan liittyvistä tekijöistä. Näillä tekijöillä muodostetaan lisäarvoa erityisesti silloin, kun tekijät tai toimintatavat ovat yhdenmukaisia asiakkaiden toimintatapojen ja arvojen kanssa.

Asiakkaalle lisäarvo muodostuu tuotteesta saadusta hyödystä sekä tuotteen saamiseksi käytetystä ajallisista ja rahallisista uhrauksista sekä riskeistä (Kemperman ja van Engelen 1999, Ravald ja Gröönroos 1996). Lähiruoan tuotteistamis- ja markkinointimahdollisuutta tarkastellaan asiakkaiden hyötyjen, riskien ja uhrausten näkökulmasta. Lähiruokatoiminnassa yrityksen tuote- ja palveluominaisuuksilla tulee olla hyötyä tuottavia sekä myös uhrauksia ja riskejä alentavia seurausvaikutuksia asiakkaille, jotta toimintamalli koettaisiin paremmaksi kuin perinteiset tarjontaketjut. Asiakkaiden odotusten ja kokemusten välinen tasapaino mm. yrityksen tuotteiden laatua kohtaan vahvistaa asiakastyytyväisyyden ja -uskollisuuden kautta yrityksen taloudellista suorituskykyä (Stoelhorst 1997, ref. Kemperman ja van Engelen 1999). 


\section{Aineisto ja menetelmät}

Tutkimuksen empiirisessä osassa tarkasteltiin lähiruokatoimintaa elintarvikealan maaseutuyritysten ja suurkeittiöiden välisessä kaupallisessa suhteessa. Suurkeittiöt ovat perinteisestikin ostaneet raakaaineita ja täydennystuotteita suoraan maatiloilta ja pienyrityksiltä. Monissa suurkeittiöissä sekä kaupallisella että julkisella puolella on ilmennyt viime aikoina kiinnostusta kehittää toimintaa tietoisemmin lähiruoka-ajattelun pohjalle. Tutkimuksen empiirisessä osassa selvitettiin lähiruokatoiminnan kokemuksia, lisäarvoja, esteitä ja kehittämistarpeita sekä maaseutuyritysten että suurkeittiöiden näkökulmista. Tutkimus toteutettiin kvalitatiivisella tutkimusotteella tapaustutkimuksena, koska systemaattisesti kerättävää aineistoa ei lähiruokatoiminnasta ole vielä saatavilla. Valittu lähestymistapa antoi mahdollisuuden lähestyä tutkimusilmiötä intensiivisesti ja eri näkökulmista sekä ilmiön ainutlaatuisten että yleisten piirteiden tunnistamiseksi (ks. Yin 1994, Stake 1995).

Tutkimusaineisto hankittiin suurkeittiöiden hankintavastaavien $(n=9)$ ja elintarvikealan maaseutuyritysten edustajien $(n=12)$ teemahaastatteluilla. Tutkimuskohteiksi valittiin sekä julkisia että kaupallisia suurkeittiöitä, joissa paikallisesta lähiruokatoiminnasta oltiin kiinnostuneita ja joissa sitä oltiin jo kokeiltu sekä suurkeittiöitä, joissa lähiruokatoiminnan toteuttamisen mahdollisuudet kyseenalaistettiin. Haastateltavat maaseutuyrittäjät valittiin kyseisten suurkeittiöiden raaka-ainetoimittajista. Teemahaastattelurungon rakentamisen perustana käytettiin aiempia tutkimuksia ja teoreettisia näkemyksiä sekä tutkijoiden hankkimaa tietoa lähiruokatuotannon ja -toiminnan nykytilasta.

Lähiruokatoimintaan liittyvien lähtökohtaoletusten perusteella muodostettiin tutkimukselle teoreettiset näkökulmat vaihtoehtoisesta tarjontaketjusta ja lisäarvon muodostumisesta, ja ne koottiin malliksi teoreettisessa viitekehyksessä (Paananen ja Forsman 2001, s. 34). Aineiston analyysi tehtiin pitkälti induktiivisesti käyttäen kuitenkin teoreettista mallia viitteellisenä tarkastelukehikkona. Luotettavuuden varmistamiseksi analyysiprosessissa noudatettiin periaatetta, jonka mukaan tiedonlähteiden ja tulosten päättelyketjua tulee voida tarkastella molempiin suuntiin, havainnoista johtopäätöksiin ja johtopäätöksistä takaisin yksittäiseen havaintoon (Yin 1994, s. 98, ks. tutkimuksen luotettavuudesta tarkemmin Paananen ja Forsman 2001).

Tutkimuksen analyysimenetelmänä sovellettiin näytteiden sopivuuden eli pattern-matching -analyysimallia, jossa verrattiin teoreettisia oletuksia ja näytteiden perusteella saatujen tulosten yhteensopivuutta (ks. Yin 1994). Aineistosta nousi esille myös runsaasti ilmiön olemusta kuvaavaa uutta perustietoa, mikä täydensi lisäarvon muodostumisen tarkastelua. Tutkimustulokset ovat yleistettävissä ensisijaisesti tutkimusaineistoon; tutkimusilmiötä ajatellen niitä tulee tarkastella suuntaa antavina.

\section{Tulokset ja tulosten tarkastelu}

Tutkimuksen perusteella lähiruoalle on kysyntää suurkeittiöissä. Nykytilanteessa ruokatarjonnan perustaminen yksinomaan lähiruokaan ei suurkeittiöissä kuitenkaan ole mahdollista. Syynä tähän on tarjonnan vähäisyys tai puuttuminen tietyissä tuoteryhmissä kokonaan. Paikalliset tarjoajat nähdäänkin useimmiten täydennystoimittajana. Kuitenkin lähiruoan käytön uskotaan suurkeittiöissä kasvavan lähivuosina. Tämä edellyttää, että paikalliset yritykset ovat nykyistä aktiivisempia tuotteiden tarjonnassaan ja että tuotteita on saatavilla säännöllisesti.

Pienyrittäjät ja suurkeittiöiden hankintavastaavat liittivät lähiruokatoimintamalliin ja lähiruokaan useita hyötyjä ja lisäarvoa tuottavia tekijöitä. Lisäarvoa muodostavia tekijöitä elintarvikeketjun kaikille toimijoille ovat tuoreet raaka-aineet, elintarvikkeiden ja valmistajien alkuperätieto sekä elintarvikkeiden lisäaineettomuus ja ruoan hyvä maku. Tutkimuksen tulokset tukevat lähtökohdaksi asetettua oletusta lähiruokatoimintamallin lisäarvoa tuottavista tekijöistä.

Pienyritysaineistosta nousi esille yritysten asiakkaille sekä toiminnallisia että emotionaalisia hyötyjä tuottavia tekijöitä (kuvio 1). Kempermanin ja van Engelenin (1999) esittämän mallin mukaisesti toiminnalliset hyödyt ovat tuotteen ja sen toimintoja kuvaavat ominaisuudet. Emotionaaliset hyödyt liittyvät asiakkaiden tunneperäisiin arvoihin. Pienyritysten haastatteluaineiston mukaan suurin osa yrittäjien tuottamista hyödyistä asiakkaille on pikemminkin toiminnallisia kuin emotionaalisia hyötyjä. Niin ikään pienyrittäjät liittävät lisäarvon muodostamisen asiakkaille ennemmin tuote- tai palveluominaisuuksien hyötyjä tuottaviin kuin uhrauksia ja riskejä alentaviin tekijöihin. Tämä voi johtua osittain siitä, että yrityksissä ymmärretään lisäarvon muodostaminen ensisijaisesti lisäominaisuuksien tai -palveluiden yhdistämisenä ydintuotteeseen. Vasta viime vuosina on muodostettu vaihtoehtoisia lähestymistapoja lisäarvon luomiseksi asiakkaalle. Vaihtoehtoisena lähestymistapana mm. Ravald ja Grönroos (1996) sekä Kemperman ja van Engelen (1999) ovat tutkineet lisäarvon muodostumista asiakkaille niiden tuotteista ja palveluista kokemien uhrauksia ja riskiä alentavien tekijöiden avulla. 


\begin{tabular}{|c|c|}
\hline $\begin{array}{l}\text { Toiminnalliset hyötyä tuottavat tekijät } \\
\text { - Tuotteen ja lajikkeen sopivuus ruoan raaka- } \\
\text { - Tuineeksi } \\
\text { - Tuotteen ja raaka-aineen hyvä suoristuskyky } \\
\text { - Asiakkaiden toiveiden mukaiset tuotteet } \\
\text { - Tuoreet ja kotimaiset tuotteet } \\
\text { - Oikean kokoiset pakkaukset } \\
\text { - Oikea pakkausmateriaali } \\
\text { - Tuotteen alkuperä- ja valmistajatiedot }\end{array}$ & $\begin{array}{l}\text { Emotionaaliset hyötyä tuottavat tekijät } \\
\text { - Ruoan houkutteleva ulkonäkö } \\
\text { - Käsityömäinen tuotantotapa } \\
\text { - Tuotteiden henkilöityminen } \\
\text { - Henkilökohtainen yhteydenpito asiakkaisiin }\end{array}$ \\
\hline $\begin{array}{l}\text { Ajallisia ja rahallisia uhrauksia } \\
\text { alentavat tekijät } \\
\text { - Esikäsittely-ja jalostusasteen nostaminen } \\
\text { - Juuresten kuoriminen } \\
\text { - Valmiit komponenttituotteet } \\
\text { - Valmis tuotetilausrunko } \\
\text { - Tilauslista elintarvikekylmiön ovessa } \\
\text { - Suorien toimitusten kilpailukykyiset hinnat } \\
\text { - Toimitusjoustavuus } \\
\text { - Pienet toimitusmäärät ja täsmätoimitukset }\end{array}$ & $\begin{array}{l}\text { Riskejä alentavat tekijät } \\
\text { - Tuotteen ja lajikkeen sopivuus ruoan raaka-aineeksi } \\
\text { - Tuotteen ja raaka-aineen hyvä suoristuskyky tarjoilussa } \\
\text { - Toimitusvarmuus sovittuna aikana ja lyhyellä varoitus- } \\
\text { ajalla }\end{array}$ \\
\hline
\end{tabular}

Kuvio 1. Pienyrittäjien käsitys lähiruoan lisäarvoon vaikuttavista tekijöistä suurkeittiöissä.

Suurkeittiöiden hankintavastaavat pitivät lähiruokatoiminnan eräänä tärkeänä toiminnallisena hyötynä tuotteiden tuoreutta ja hyvää laatua. Myönteisenä seurauksena tästä tuotteiden hävikki etenkin tuoretuotteissa voi pienentyä. Alhainen tuotehävikki voi puolestaan laskea suurkeittiöiden elintarvikehankintojen kokonaiskustannuksia. Lisäksi lähiruokatoiminnan lisäarvona koettiin elintarvikeketjun läpinäkyvyys ja tuotteiden lisäaineettomuus. Elintarvikeketjun läpinäkyvyys antaa mahdollisuuden vahvistaa tulevien sukupolvien arvostusta ja suhdetta ruokaan ja ruoan tuotantoon sekä lisätä ruoan turvallisuutta (kuvio 2).

\begin{tabular}{|c|c|}
\hline $\begin{array}{l}\text { Toiminnalliset hyödyt } \\
\text { - Ruokalistan joustavuus } \\
\text { - Tuotteiden käsiteltävyys, tuoreus ja laatu } \\
\text { - Alhainen hävikin osuus } \\
\text { - Alhainen varastoinnin tarve } \\
\text { - Asiakaslähtöinen } \\
\text { - Maakunnan ruokaperinteiden säilyminen } \\
\text { - Alueellisuus } \\
\text { - Alueellinen työllistyminen ja viihtyminen } \\
\text { - Maaseudun elinvoimaisuus } \\
\text { - Luonnon kestävyys } \\
\text { - Ympäristömyötäisyys } \\
\text {-Energian säästyminen }\end{array}$ & $\begin{array}{l}\text { Emotionaaliset hyödyt } \\
\text { - Ruoan terveellisyys } \\
\text { - Lisäaineeton } \\
\text { - Ravitsemuksellinen } \\
\text { - Elintarviketuotannon ja -valmistusketjun läpinäky- } \\
\text { vyys } \\
\text { - Ruoan turvallisuus } \\
\text { - Kasvatuksellinen ja markkinoinnillinen arvo } \\
\text { - Viihtyminen suurkeittiötyössä }\end{array}$ \\
\hline $\begin{array}{l}\text { Ajalliset ja rahalliset uhraukset } \\
\text { - Ruokareseptien uudelleenluonti } \\
\text { - Uusien tavarantoimitussuhteiden perustaminen } \\
\text { - Tarpeiden mukaisten tuotteiden löytäminen } \\
\text { - Uusi ajattelutapa hankintatoiminnoista ja ruuanval- } \\
\text { - mistuksesta } \\
\text { - Useasta paikasta tilaaminen lisää hankintakustan- } \\
\text { nuksia } \\
\text { - Lisää työtä varastokirjanpidossa }\end{array}$ & $\begin{array}{l}\text { Tuote- ja systeemiriskit } \\
\text { - Tuotteiden tarjonta epätasaista tai vähäistä } \\
\text { - Uuden yhteistyön aloittaminen uusien tavarantoi- } \\
\text { mittajien kanssa } \\
\text { - Uuden pienyrittäjän pitkän aikavälin tavarantoimi- } \\
\text { - tuskyky } \\
\text { - Uuden pienyrittäjän tavarantoimitusvarmuus }\end{array}$ \\
\hline
\end{tabular}

Kuvio 2. Lähiruokatoimintamallista koetut hyödyt, uhraukset ja riskit suurkeittiöissä.

Lähituotteissa lisäaineiden, mm. säilöntäaineiden määrän tarpeen oletetaan vähenevän, kun tuotteen toimituksen ja käytön välinen ajallinen yhteys on mahdollisimman pieni. Lähiruokatoimintamallia hyödyntävien suurkeittiöiden hankintavastaavien yhdeksi keskeisimmäksi emotionaaliseksi hyödyksi nousi toimintamallin positiivinen vaikutus suurkeittiötyössä viihtymiseen, sillä se tuo monipuolisuutta elintarvikeraaka-aineiden hankintaan ja ammattitaitoiseen ruoanvalmistukseen.

Lähiruokatoiminta vaatii suurkeittiöiltä sekä ajallisia että rahallisia uhrauksia, ja siitä voi aiheutua myös riskejä. Lähiruokatoiminnan toteuttamisessa aiheuttaa eniten työtä ruokareseptien uudelleenluominen, uusien tavarantoimitussuhteiden perustaminen ja tarpeisiin sopivien tuotteiden löytäminen, uuden ajattelutavan omaksuminen hankintatoiminnoissa ja ruoan valmistuksessa sekä töiden uudelleen organisointi. Pienyritysten tuotteiden pienten tarjontamäärien takia raaka-aineita ja tuotteita joudutaan hankkimaan useasta paikasta. Tämä puolestaan lisää suurkeittiöiden tuotteiden varastokir- 
janpitoa ja tilaus- ja laskutustoimintoja sekä elintarvikehankintojen kustannuksia suurkeittiöissä. Lähiruokatoiminnan systeemiriskinä pidettiin tuotteiden tarjonnan vähäisyyden ja epätasaisuuden lisäksi pienyritysten tavarantoimituskykyä esimerkiksi reklamaatiotapauksessa.

\section{Johtopäätökset}

Tutkimuksessa hyödynnetty asiakasarvon malli (Kemperman ja van Engelen 1999) soveltuu hyvin lähiruokatoimintamallin yrittäjä-asiakassuhteessa muodostuvien hyötyjen, uhrauksien ja riskien tarkasteluun. Lähiruoan loppukuluttajille muodostuvan lisäarvon selvittäminen edellyttää, että lähiruokatoiminta on jossain määrin vakiintunutta ja lähiruoka käsitteenä tiedostetaan. Ketjun alkupäässä elintarvikealan yrittäjillä ja esimerkiksi ruokapalveluja tarjoavilla suurkeittiöillä on tärkeä rooli lähiruokaan liitettävien oikeiden mielikuvien ja käsitysten luomisessa. Lähiruoalla pystytään luomaan kestävää lisäarvoa elintarvikeketjun eri toimijoille vain lähiruoasta muodostetun oikean mielikuvan ja siihen liitettävien todellisten ja perusteltujen argumenttien avulla.

Lähiruoan ja paikallisuuden markkinoinnissa tulisi käyttää aikaisempaa tehokkaammin asiakasta puhuttavia argumentteja. Siksi arvopohjainen lähestymistapa soveltuu hyvin lähiruoan markkinointiin. Arvoihin perustuvassa markkinoinnissa selvitetään, mitä hyötyjä lähiruoan käytöstä on asiakkaalle, esimerkiksi vähäinen pakkaustarve, alkuperätieto tai tuoreet tuotteet. Edelleen selvitetään, mitä omia päämääriään asiakas voi lähiruoan käytöllä saavuttaa, esimerkkinä ajallinen säästö pakkausten hävittämisessä, ympäristöystävällisyys, elintarvikeketjun läpinäkyvyys tai elintarvikekustannusten hallinta. Hyödyntämällä mahdollisimman asiakaslähtöisiä markkinointiperusteita lähiruoan tuotteistaminen ja markkinointi on tehokasta ja herättää asiakkaiden kiinnostuksen.

Lähiruokatoiminnan yleistyminen riippuu pitkälti siitä, miten lähiruokatuotannon toimintaedellytyksiä vahvistetaan ja kehitetään lähiruokakysynnän mukaiseksi. Lähiruokatuotannon tulisi vastata sekä määrällisesti että laadullisesti kohdeasiakkaiden tarpeita. Tarpeiden selvittämisen lisäksi tarvitaan myös toimijoiden keskinäistä tiivistä yhteistyötä esimerkiksi tuote- ja varastointisuunnittelussa. Lähiruokatoimintamallissa lisäarvon muodostaminen asiakkaille edellyttää elintarvikeketjun kokonaisuuden ja eri toimijoiden päämäärien sekä niiden mukaisten arvojen tunnistamista. Lähiruokakokeilujen vakiinnuttua ja yleistyttyä voidaan myös paremmin arvioida paikallisten elintarvikeketjujen yhteiskunnallista merkitystä tutkimalla lähiruokaan liitettäviä aluetaloudellisia, ekologisia ja sosiaalisia vaikutuksia. Näiden vaikutusten tutkimiseen tarvitaan laaja-alaista poikkitieteellistä lähestymistapaa.

\section{Kirjallisuus}

Aro, J. 1998. Suurkeittiöt elintarvikealan pienyritysten markkinointikanavana. Maatalouden taloudellisen tutkimuslaitoksen selvityksiä 3/98. Helsinki. 44 s.

Kemperman, J. E. B. \& van Engelen, M. L. 1999. Operationalizing the customer value concept. A paper presented in the $28^{\text {th }}$ EMAC Conference "Marketing and Competition in the information age". Berlin, May 11-14, 1999.

La Trobe, H. L. \& Acott, T. G. 2000. Localising the global food system. International Journal of Sustainable Development and World Ecology 7:309-320.

Markula, J. 1999. Suurkeittiöiden elintarvikeostot maaseutuyrityksiltä. Maatalouden taloudellisen tutkimuslaitoksen selvityksiä 1/99. Helsinki. $44 \mathrm{~s}$.

Marsden, T. 2000. Food Matters and the Matter of Food: Towards a New Food Governance. Sociologia Ruralis 40(1): 20-29.

Marsden, T. K. \& Arce, A. 1995. Constructing quality: emerging food networks in the rural transition. Environment and Planning A 27:1261-1279.

Marsden, T., Banks, J. \& Bristow, G. 2000. Food Supply Chain Approaches: Exploring their Role in Rural Development. Sociologia Ruralis 40(4): 425-438.

Paananen, J. \& Forsman, S. 2001. Lähiruoka elintarvikealan maaseutuyritysten ja suurkeittiöiden kokemana. Taloustutkimus (MTTL), tutkimuksia 252. Helsinki. 94 s.

Ravald, A. 2001. A View of Value - The Customer Value Process Approach. A paper presented in the $30^{\text {th }}$ EMAC Conference "Rethinking European Marketing". Norway, May 8 - 11, 2001.

Ravald, A. \& Gröönroos, C. 1996. The Value Concept and Relationship Marketing. European Journal of Marketing 30(2):19-30.

Stake, R. E. 1995. The Art of Case Study Resesarch. Sage Publications, California. $171 \mathrm{~s}$.

Stoelhorst, J-W. 1997. In Search of a Dynamic Theory of the Firm. Doctoral dissertation. University of Twente. Woodruff, R.B. 1997. Customer Value: The Next Source for Competitive Advantage. Journal of the Academy of Marketing Science 25(2):139-153.

Yin, R. K. 1994. Case Study Research - Design and Methods. $2^{\text {nd }}$ edition. Sage Publications, USA. 212 s. 